\title{
The impact of South African real estate investment trust legislation on firm growth and firm value
}

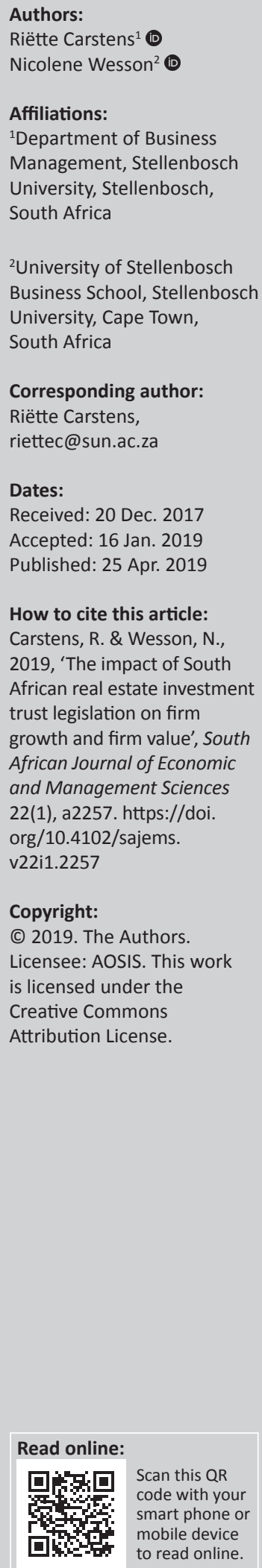

Background: Through the introduction of the South African real estate investment trust (SA REIT) structure, listed property investment firms are required to conform to international REIT standards, thereby making REITs more attractive to investors. Despite the exponential growth of the SA REIT industry over the past decade, SA REIT legislation - effective from 2013 - has imposed regulations with regard to financial leverage and profit retention, which may affect these firms' sustainable growth rate and firm value.

Aim: By deconstructing the sustainable growth rate, we investigated the potential impact of SA REIT legislation on growth rate components and considered the impact of each growth component on firm value.

Setting: The introduction of SA REIT legislation provides an opportunity to investigate how regulation has affected REIT growth and value.

Methods: We investigated changes in the respective sustainable growth rate components using a mixed model analysis of variance. Additionally, we employed a panel regression to assess the impact of each component on firm value (proxied by Tobin Q).

Results: We found empirical evidence of decreased leverage and profit retention, as well as increased profit margins, in the REIT period, which may be indicative of firms' reaction to regulation. In addition, we found that profit retention had a significant positive impact on firm value, while leverage showed a significant negative effect on firm value post-legislation.

Conclusion: This study confirmed a significant change in growth components, with higher average profitability and sustainable growth in the REIT period, suggesting that the REIT industry responded positively to the REIT regime introduction.

Keywords: REIT; real estate investment trust; sustainable growth; firm value; South Africa.

\section{Introduction}

Since their inception in 1960 in the United States, real estate investment trusts (REITs) have become a global standard for listed property investment firms and have been introduced in more than 34 countries (Brounen \& De Koning 2012). Following the global precedent, REIT legislation was adopted in South Africa in 2013, bringing about legislative changes that affect the ability of SA REITs to retain profits and incur debts. Real estate investment trusts are characterised as being capital-intensive and highly leveraged firms (Case, Hardin \& Wu 2012), which raises the question as to whether REIT legislation has had an impact on firm growth and firm value.

Given the high-growth environment and global competitive scope, South African (SA) REITs experience increasing pressure to grow. High growth may result in SA REITs growing at an unsustainable rate, while low-growth REITs may be seen as attractive for takeovers (Ashta 2008). The SA REIT industry-specific regulations on profit retention and financial leverage may, however, affect the ability of REITs to grow sustainably. With real estate investments defining the core business of REITs, financial leverage and retained profits enable REITs to acquire these investments. As such, the expectation exists that firm value will be affected by changing regulation that informs debt and dividends in particular.

The purpose of this study was to investigate REIT growth, using the sustainable growth rate (SGR) measure, in the pre-REIT and REIT periods by evaluating changes in the four SGR components, namely the profit retention rate, financial leverage, profit margin and asset turnover. Additionally, focusing on the SGR components directly affected by REIT legislation, we evaluated the effect of financial leverage and profit retention on firm value (measured in terms of Tobin Q) in the pre-REIT and REIT regime. 
While existing literature emphasises REIT-specific capital constraints (Ott, Riddiough \& Ha-Chin 2005; Stein 2003), the impact of leverage and profit retention on REIT value, specifically in the South African context, is under-researched. We reduced this gap in REIT literature by investigating the impact of retention rates and leverage on firm value. Our study may benefit REIT managers and practitioners in emphasising the potential impact of REIT legislation on firm growth and firm value. Furthermore, our findings may assist in assessing and developing appropriate capital structures and dividend policies in the SA REIT regime.

The study is organised as follows: in the upcoming section, recent changes in the South African listed property sector are examined and the potential impact of the REIT structure on REIT growth and firm value are discussed. The data and methodology are then defined, the results explained and a conclusion drawn.

\section{The South African listed property sector and South African real estate investment trusts}

Prior to the introduction of REITs, the property sector listed on the Johannesburg Stock Exchange (JSE) consisted of two property investment structures, namely property unit trusts and property loan stock companies. Property unit trusts were governed by trust deeds and were subject to Financial Services Board (FSB) regulations in terms of the Collective Investment Schemes Control Act (National Treasury 2012:66), while property loan stocks adhered to the Companies Act and JSE regulations. As a result, the regulation of the listed property sector was fragmented and tax treatment between the two structures differed (Kantilal 2016), adversely affecting investment confidence. With the implementation of the REIT structure in May 2013, property unit trusts converted to trust REITs and property loan stocks to company REITs (JSE n.d.). The introduction of the SA REIT structure brought about regulatory requirements to better align the South African listed property industry to international standards and to transform the industry to become more globally competitive (Naidoo 2014). Real estate investment trusts own and manage rental property and offer investors the opportunity of investing indirectly in a variety of property types managed by property professionals. As such, REITs are highly capitalintensive firms that grow their businesses through real estate acquisitions, improving the efficiencies of their real estate investments, or by developing new properties.

The increased prominence of SA REITs is evident from their $5.8 \%$ representation on the FTSE/JSE All Share Index, which, in terms of market capitalisation in August 2015, exceeded the market capitalisation of both the retail sector (at 5.7\%) and the healthcare sector (at 3.9\%) (SA Commercial Prop News 2015). During 2014 and 2015, the market capitalisation of SA REITs increased by about $43 \%$ (Rapp 2015). This brought the total market capitalisation for SA REITs to R340 billion towards the end of 2015. South African real estate investment trusts increased their presence even further in 2016, when three additional SA REITs were included in the JSE FTSE Top 40, bringing the total number of REITs represented in the Top 40 index to five (Financial Times n.d.). It is approximated that $23 \%$ of commercial property in South Africa, estimated at a total value of R1.3 trillion, is owned by SA REITs (SA REIT Association 2016b).

The requirements for a firm to be listed as a REIT on the JSE include owning property investments of at least R300 million, deriving at least $75 \%$ of the firm's income from rental or property investment income, distributing at least $75 \%$ of the firm's annual distributable taxable earnings, and maintaining debt levels that do not exceed $60 \%$ of the gross asset value (SA REIT Association 2016a).

\section{An overview of sustainable growth rate and firm value}

The introduction of the REIT structure imposed debt limitations and set minimum dividend payment levels, constraining capital in a capital-intensive industry (Ott et al. 2005). With SA REIT legislation influencing internal and external capital funding - and in line with the international study by Ott et al. (2005) - we expect SA REIT growth and firm value to be affected in the post-legislation period.

\section{Sustainable growth rate components}

High industry growth is positively received by REIT shareholders and owners alike. However, the increased JSElisted footprint of SA REITs needs to be underpinned by longterm sustainability, ensuring long-term survival. The SGR portrays a firm's ability to grow sustainably. Sustainable growth rate is defined as the profit retention rate (or profit retention) multiplied by the return on equity (ROE), with ROE determined by multiplying the net profit margin, asset turnover and financial leverage (Investopedia n.d.). Firer et al. (2012) explain the importance of each of these components. The profit retention rate displays the firm's dividend policy, which affects retained income and the equity available to attain sustainable growth. The profit margin displays operating efficiency and the ability to generate profit that will contribute to the ability to grow sustainably. Total asset turnover shows the ability to use assets efficiently to generate turnover, because an increased asset turnover implies a lower capital intensity, resulting in a higher SGR. Lastly, an increase in available financial leverage results in a higher SGR, all things being equal.

Empirical evidence shows that high-growth firms generally prefer a lower payout ratio (therefore a higher profit retention rate) in order to reinvest earnings in investment opportunities that display positive net present values (Liow 2010). However, REITs are subject to high mandatory dividend payments, implying low retention rates. In fact, retained earnings have only contributed $7 \%$ towards investment financing of REITs - in contrast to approximately $70 \%$ for industrial companies (Fama \& French 1999; Ott et al. 2005). 
Consequently, long-term investments of REITs are funded mainly with debt and equity, and not with retained earnings (Feng, Ghosh \& Sirmans 2007; Ott et al. 2005).

Increased profitability is expected to accompany sustainable growth (Holliday 2001). Liow (2010) found a significantly positive relationship between a firm's growth rate and its profitability. However, the impact of profitability on financial leverage must also be considered, as the pecking order theory suggests that profitable companies will prefer financial leverage over issuing equity, owing to the negative signal that is associated with issuing equity (Harrison, Panasian \& Seiler 2011). Contrarily, Giambona, Harding and Sirmans (2008) found that more profitable companies display lower debt ratios. Feng et al. (2007) agree that more profitable firms have more internal cash available, which leads to less borrowing and a positive relationship between profitability and equity finance (Hada \& Avram 2014). In respect of asset turnover, evidence suggests that it is predominantly determined by the firm's products, competitive strategy and management's capability to manage assets effectively (Higgins 1992). The effective use of real estate assets is essential to grow REITs sustainably as assets that do not deliver the expected yield can be considered an ineffective application of financial resources.

\section{Firm value}

Real estate investments trusts are characterised by high mandatory dividend payouts (therefore low profit retention rates), which emphasises the importance of external capital to grow their capital-intensive business (Case et al. 2012). However, the use of external capital by REITs is limited in terms of REIT legislation, which may limit the ability of REITs to make real estate investments and as a result affect firm value (Stein 2003). The impact of financial leverage on firm value has been investigated for non-real estate industries (Lin \& Chang 2011), but similar studies on REITs are lacking - particularly considering the impact of changing industry legislation on leverage and profit retention levels. This investigation complements existing literature on the impact of financial leverage on firm value, using Tobin $Q$ as a proxy for firm value from the investor's perspective, in line with previous investigations (Farooq \& Masood 2016). Furthermore, our study ascertains the significance of the relationship between financial leverage and firm value, focusing on the SA REIT industry.

Tobin $Q$ is generally used in studies investigating real estate firm performance and value (Feng, Price \& Sirmans 2011; Lin $\&$ Chang 2011). In line with existing literature, we proxy firm value using Tobin $Q$, which represents the stock market value relative to the underlying property market value of firm assets (Capozza \& Seguin 2000). As an ex ante measure, the Q ratio is also indicative of the expected future performance (Capozza \& Seguin 2000) of REITs.

\section{Data and methodology Data collection}

The study included all firms that transformed into REITs, as well as newly listed REITs, following the REIT introduction.
These firms were listed as REITs, a sub-sector of the JSE financials sector. To avoid survivor bias, all delisted REITs were included in the analysis. Financial information required for the SGR component analysis was obtained from the INET BFA database, which contained 53 REITs (42 listed and 11 delisted) for the period of analysis. Since the data set included recently listed REITs as well as REITs that were delisted during the period under review, the panel data set was unbalanced. Based on available financial information, a total of 13 REITs (10 listed and 3 delisted) were included in the preREIT period and 22 REITs (18 listed and 4 delisted) in the REIT period analysis. Appendix 1 displays the final sample of REITs used for the analysis. The pre-REIT period was defined as January 2009 to April 2013, with May 2013 to December 2016 as the REIT period. Data from 2013 were allocated to the pre-REIT or REIT period depending on the financial year ends of the REITs.

Data were obtained from annual financial reports, as reported via the IRESS database. The annual profit retention rate and profit margin per REIT were obtained from the IRESS database (the Financial Ratios product module) and the asset turnover and financial leverage ratios were calculated using available financial data from IRESS (the Financial Statement product module). For asset turnover, sales (INET BFA line item 02020060) were used as the numerator with total assets (INET BFA line item 02010050) as the denominator, while leverage was calculated using total assets (INET BFA line item 02010050) as numerator and equity (INET BFA line item 02010013) as denominator. In addition, Tobin Q figures and market capitalisation data were sourced from the IRESS database (the Financial Models and Price Data modules). The data were collected in data panel format, and a panel regression was performed using the PLM package in R. Additionally, a mixed model analysis of variance (ANOVA) was performed using the VEPAC module in Statistica 13.

\section{Data cleaning and methodology}

Outliers were subject to winsorising by changing the values to the trimmed mean plus or minus three standard deviations. A $10 \%$ trimmed mean and standard deviation was used. Tolerance indices were calculated for all the independent variables and none were found to be less than 0.2 , indicating no multicollinearity among the predictor variables (Table 1). Additionally, adjusted p-values were calculated to adjust for heteroscedasticity.

First, we compared the change for each of the sustainable growth components from the pre-REIT period to the REIT period, using a mixed model ANOVA. Second, we determined

TABLE 1: Tolerance indices.

\begin{tabular}{lccc}
\hline Variable & \multicolumn{3}{c}{ Tolerance $\mathbf{0 . 8 0}$} \\
\cline { 2 - 4 } & Full period & Pre-REIT period & REIT period \\
\hline Profit margin & 0.86 & 0.80 & 0.85 \\
Retention rate & 0.78 & 0.77 & 0.78 \\
Asset turnover & 0.95 & 0.96 & 0.90 \\
Financial leverage & 0.70 & 0.67 & 0.71 \\
\hline
\end{tabular}

REIT, real estate investment trust. 
TABLE 2: Descriptive statistics for the pre-real estate investment trust and real estate investment trust periods.

\begin{tabular}{|c|c|c|c|c|c|c|c|c|c|c|}
\hline \multirow[t]{2}{*}{ Variable } & \multicolumn{2}{|c|}{ Mean } & \multicolumn{2}{|c|}{ Median } & \multicolumn{2}{|c|}{ Minimum } & \multicolumn{2}{|c|}{ Maximum } & \multicolumn{2}{|c|}{ Standard deviation } \\
\hline & Pre-REIT & REIT & Pre-REIT & REIT & Pre-REIT & REIT & Pre-REIT & REIT & Pre-REIT & REIT \\
\hline Profit margin & 42.74 & 84.45 & 42.73 & 81.61 & 89.28 & 89.28 & 222.94 & 222.94 & 55.57 & 55.90 \\
\hline Dividend retention rate & 82.90 & 64.91 & 100 & 70.96 & 26.12 & 26.12 & 137.25 & 133.99 & 37.05 & 36.84 \\
\hline Asset turnover & 0.12 & 0.12 & 0.12 & 0.12 & 0.07 & 0.04 & 0.23 & 0.23 & 0.04 & 0.04 \\
\hline Financial leverage & 3.34 & 2.78 & 2.47 & 1.92 & 1.05 & 1.04 & 7.85 & 7.85 & 2.21 & 2.01 \\
\hline Sustainable growth rate & 0.11 & 0.19 & 0.07 & 0.12 & -0.40 & -0.46 & 0.73 & 0.73 & 0.25 & 0.23 \\
\hline
\end{tabular}

REIT, real estate investment trust.

the impact of these four components on firm value (proxied by Tobin Q). The Hausman test for random effects was performed to determine if a fixed or random effects model was appropriate. According to this test, if the null hypothesis is rejected, the fixed effects model must be applied. Alternatively, if the null hypothesis is not rejected, the random effects model is appropriate (Belgrove \& Van der Merwe Smit 2016). The null hypothesis was rejected at a 5\% significance level for all periods analysed, leading to a fixed effects model being used. The generalised regression model in Equation 1 was applied to the pre-REIT and REIT periods:

$T Q_{i t}=\beta_{0}+\beta_{1} X+\beta_{2} Y+\varepsilon$

[Eqn 1]

In Equation 1, $T Q_{i t}$ is Tobin $Q$ for REIT $i$ in year $t, X$ is the set of SGR components and $Y$ is a firm-level control variable. The model controls for firm size using the log of firm market capitalisation.

\section{Results}

\section{Changes in sustainable growth rate components over time}

The profit margin and SGR displayed increased means from the pre-REIT period, with the asset turnover remaining unchanged (Table 2). Conversely, retention rates and financial leverage decreased on average (Table 2), which may be indicative of the effect of REIT regulation that limits debt levels and mandates high dividend payments.

Using a mixed model ANOVA, we investigated significant changes between the pre-REIT and REIT periods. A higher average SGR, albeit less prominent at $10 \%$ significance, is evident in the REIT period (Table 3). One explanation may be the lower investor confidence in the pre-REIT period in an industry that was only partly regulated owing to different investment structures, namely property unit trusts and property loan stocks (Kantilal 2016). A significant decline in the average financial leverage is shown at the $1 \%$ level, which is most likely attributable to the debt limitation in the post-REIT period. Additionally, as REITs become more globally competitive, maintaining an acceptable investment grade credit rating becomes increasingly important, affecting leverage ratios as a result (Feng et al. 2011). In line with Case et al. (2012), periods of higher leverage were associated with lower dividends as higher profit retention assisted in reducing going-concern risk. As expected, a reduction in the average retention rate is evident at $5 \%$ significance, implying higher dividend payouts in the REIT period. Conversely, Wang, Erickson and Gau (1993) suggest that higher dividend payments may be enabled by higher
TABLE 3: Mean differences between the pre-real estate investment trust and real estate investment trust period.

\begin{tabular}{lccc}
\hline Variable & Pre-REIT period & REIT period & F-statistic \\
\hline Profit margin & 42.74 & 84.45 & $28.65^{* * *}$ \\
Dividend retention rate & 82.90 & 64.91 & $5.80^{* *}$ \\
Asset turnover & 0.12 & 0.12 & $5.97^{* *}$ \\
Financial leverage & 3.34 & 2.78 & $11.89 * * *$ \\
Sustainable growth rate & 0.11 & 0.19 & $3.32^{*}$ \\
\hline
\end{tabular}

REIT, real estate investment trust.

*, Significance level at $10 \%$; *, significance level at $5 \%$; ***, significance level at $1 \%$.

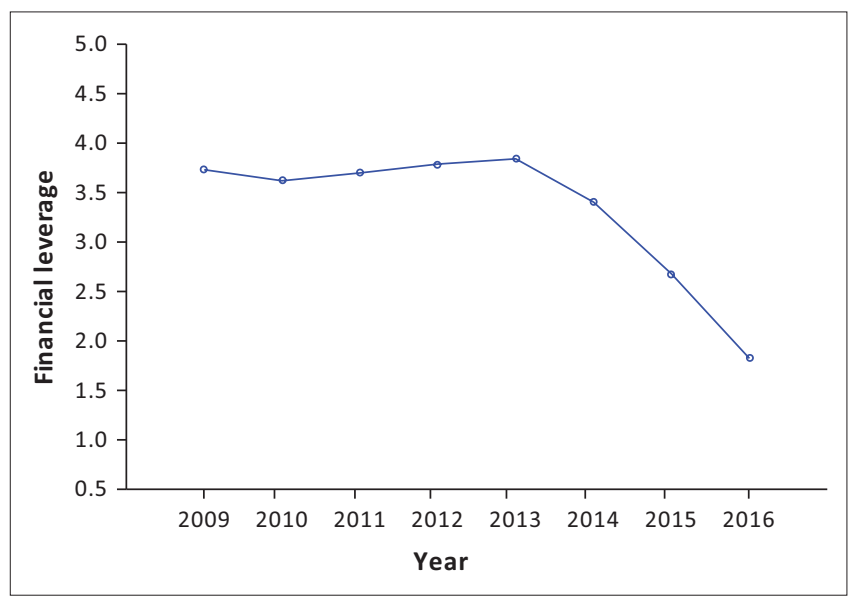

FIGURE 1: Fisher least significant difference results for financial leverage.

debt levels. However, given significant lower debt levels during the REIT period, our findings suggest that the higher dividend payouts are facilitated by significantly higher profit margins. With lower average financial leverage levels in combination with higher dividend payout rates, improved profitability becomes more important for firm growth, diminishing the ability of the firm to use retained funds to grow. The average asset turnover remained unchanged, indicating similar efficiencies in using its assets to generate revenue (Pellika 2009) across periods. Consistent efficiency is not surprising because REITs rely on their real estate assets to perform and produce revenue to achieve the desired yield for their investors.

Using Fisher least significant difference (LSD) post hoc tests, we investigated the statistical difference between the means of pairs. Figures 1 and 2 display the most significant independent variable changes, namely in the mean financial leverage and mean profit margin. In line with expectations, financial leverage showed a significant decrease as financial leverage levels were capped with the introduction of REIT policy. However, higher profitability in the REIT period showed the increasing prominence of profitability that may indicate the improved ability of REITs to control costs (Ma \& Michayluk 
2014; Pellika 2009). Our finding was consistent with studies which suggest that high growth of REITs enables firms to decrease costs by means of economies of scale as revenue increases (Ambrose, Highfield \& Linneman 2005; Feng et al. 2011; Linneman 1997). However, it is noteworthy that the average profitability of SA REITs increased significantly despite extreme increases in costs like rates and taxes, and electricity. With rising rates and taxes negatively affecting gross rentals and operating costs, and becoming an increasing industry concern, the South African Property Owners Association appointed specialists to actively monitor rates policies (Propertywheel 2017). Additionally, municipal electricity tariffs increased by $86.5 \%$ from the beginning of 2008 to July 2016 (Property News 2016). Lower average financial leverage levels furthermore imply that interest expenses decreased in the REIT period, contributing to firm profitability.

The exact reasons for significant higher profitability in the REIT period are beyond the scope of this study, but may be partially attributed to increasing rental income over time, to higher quality property portfolios that justify higher rentals or to more effective management of property expenses. However, our findings confirm those of earlier studies (Barclay, Smith \& Morellec 2006; Fama \& French 2002; Ma \& Michayluk 2014; Titman \& Wessels 1988) that more profitable firms display lower levels of financial leverage.

\section{The effect of sustainable growth rate components on firm value}

Significant pairwise correlations between the retention rate and financial leverage and firm value (proxied by Tobin $Q$ ) is

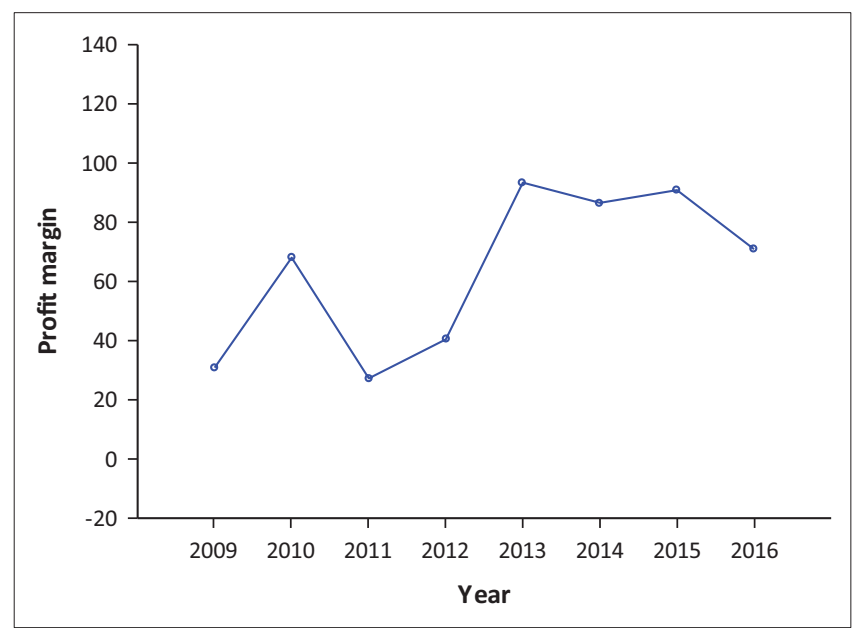

FIGURE 2: Fisher least significant difference results for profit margin. evident in the pre-REIT period (Table 4). Our findings suggest that, during the unregulated pre-REIT period, high-leveraged REITs retained more funds by reducing dividends (Case et al. 2012). However, the correlation of retention rates with firm value weakened in the REIT period to an insignificant level as REITs became subject to high dividends that significantly reduced profit retention rates (Table 3). Similarly, the Tobin Q correlation with financial leverage became insignificant in the regulated REIT period. The negative correlation between financial leverage and profit margin in the pre-REIT period suggests that the interest expense that accompanied higher debt levels lowered firm profit. Significant correlations were found in the REIT period between asset turnover and financial leverage, and asset turnover and profit margin, indicating REITs' use of leverage as they use their real estate assets to generate turnover. The negative correlation of asset turnover with the profit margin in the REIT period was expected, owing to the capital intensiveness of REITs, suggesting that the increased growth and profitability in the REIT period increased capital intensity, which lowered asset turnover.

Our regression model tested the impact of the SGR components on firm value in the pre-REIT and REIT periods. The regression results (Table 5) confirmed that neither asset turnover nor the profit margin had a significant impact on firm value in either of the periods. However, we expect the effect of financial leverage and profit retention on firm value to change over time as these SGR components were directly affected by REIT legislation. This study provides evidence (Table 5) that financial leverage had a significant impact on Tobin Q in the REIT period. Owing to the capital intensity of REIT investments, access to funds affects their ability to acquire or improve real estate assets; that is, to grow their asset base (Ambrose et al. 2005). Consequently, the importance of financial leverage for firm value is expected to increase as the REITs continue to grow their real estate investments. Another explanation may be that financial leverage is less expensive than equity financing, especially considering the decreasing prime interest rates over the period, with interest rates at $15 \%$ in January 2009 decreasing to $10.5 \%$ in December 2016 (Tradingeconomics n.d.). In addition, SA REITs are increasingly investing in global real estate that is financed at even lower foreign interest rates. This is in line with the pecking order theory that firms use the least expensive funding to finance growth (Feng et al. 2011). With SA REIT legislation prescribing lower leverage levels, firm value worsens (improves) as financial leverage increases (decreases)

TABLE 4: Pairwise correlations of sustainable growth rate components with Tobin $Q$ for the pre-real estate investment trust and real estate investment trust periods.

\begin{tabular}{|c|c|c|c|c|c|c|c|c|c|c|}
\hline \multirow[t]{2}{*}{ Variable } & \multicolumn{5}{|c|}{ Pre-REIT period } & \multicolumn{5}{|c|}{ REIT period } \\
\hline & $\begin{array}{l}\text { Tobin } \\
\text { Q ratio }\end{array}$ & $\begin{array}{l}\text { Dividend } \\
\text { retention rate }\end{array}$ & $\begin{array}{l}\text { Financial } \\
\text { leverage }\end{array}$ & $\begin{array}{c}\text { Asset } \\
\text { turnover }\end{array}$ & $\begin{array}{l}\text { Profit } \\
\text { margin }\end{array}$ & $\begin{array}{l}\text { Tobin } \\
\text { Q ratio }\end{array}$ & $\begin{array}{l}\text { Dividend } \\
\text { retention rate }\end{array}$ & $\begin{array}{l}\text { Financial } \\
\text { leverage }\end{array}$ & $\begin{array}{l}\text { Asset } \\
\text { turnover }\end{array}$ & $\begin{array}{l}\text { Profit } \\
\text { margin }\end{array}$ \\
\hline Tobin Q ratio & 1.00 & - & - & - & - & 1.00 & - & - & - & - \\
\hline Financial leverage & $0.562 * * *$ & $0.311 * *$ & 1.00 & - & - & -0.016 & -0.027 & 1.00 & - & - \\
\hline Asset turnover & 0.004 & -0.088 & 0.059 & 1.00 & - & 0.055 & 0.152 & $0.289 * *$ & 1.00 & - \\
\hline Profit margin & $-0.278 * *$ & -0.187 & $-0.291 * *$ & 0.056 & 1.00 & 0.161 & -0.103 & -0.003 & $-0.334 * * *$ & 1.00 \\
\hline
\end{tabular}

REIT, real estate investment trust.

$*$, Significance level at $10 \%$; **, significance level at $5 \%$; ***, significance level at $1 \%$. 
TABLE 5: Regression results for Tobin $Q$ for the pre-real estate investment trust and real estate investment trust periods.

\begin{tabular}{|c|c|c|c|c|}
\hline \multirow[t]{2}{*}{ Variable } & \multicolumn{2}{|c|}{$\begin{array}{l}\text { Pre-REIT period: } \\
\text { Coefficient estimate }\end{array}$} & \multicolumn{2}{|c|}{$\begin{array}{l}\text { REIT period: } \\
\text { Coefficient estimate }\end{array}$} \\
\hline & Coefficient & T-statistic & Coefficient & T-statistic \\
\hline Financial leverage & 0.147 & 1.148 & -0.059 & $-2.203 * *$ \\
\hline Retention rate & 0.279 & $3.589 * * *$ & 0.246 & $2.088 * *$ \\
\hline Profit margin & 0.013 & 0.282 & 0.091 & 0.797 \\
\hline Asset turnover & 0.008 & 0.154 & 0.157 & 1.364 \\
\hline
\end{tabular}

REIT, real estate investment trust.

$*$, Significance level at $10 \% ; * *$, significance level at $5 \% ; * * *$, significance level at $1 \%$.

after legislation has been introduced. As legislation penalises high debt levels in the REIT period, high leverage diminishes firm value. However, financial leverage displayed a positive, albeit insignificant, relationship in the pre-REIT period. This pre-REIT finding is in line with Lin and Chang (2011), who report that the significant relationship between leverage and firm value disappeared at higher debt levels.

The effect of profit retention on firm value weakened in the REIT period as REITs became subject to mandatory minimum dividend payments. This finding is in line with previous studies that emphasise the inability of retained earnings to drive REIT growth owing to high payout ratios (Rozeff 1982; Wang et al. 1993), thus reducing its impact on REIT value.

Surprisingly, the mean value of Tobin Q (not reported) decreased from 1.110 in the pre-REIT period to a significantly lower level (at 1\% significance) of 0.994 in the REIT period. In line with Lin and Chang (2011), who report a significant decrease of Tobin $Q$ during times of economic recession, lower REIT period $Q$ levels may be as a result of lower domestic economic growth. With higher Tobin Q levels also indicative of growth opportunities (Lang, Ofek \& Stulz 1996; Pavlov, Steiner \& Wachter 2016), lower Tobin Q levels may suggest that the growth opportunities, and the domestic opportunities in particular, of REITs are increasingly difficult to find, as REITs explore and increase their offshore real estate holdings. The higher pre-REIT Tobin $\mathrm{Q}$ level may also be associated with an increased requirement for external capital (Ghosh \& Sun 2014), which agrees with our finding of higher leverage in the pre-REIT period (Table 3). Tobin Q also suggests easier capital market access (Hardin \& Hill 2008), which aligns with lower financial leverage levels (Table 3) during the lower Tobin Q REIT period. Additionally, increased growth opportunities are also linked to a preference for debt over equity, leading to higher financial leverage (Feng et al. 2007), as shown in our pre-REIT results.

\section{Conclusion}

This study investigated the effect of REIT legislation on the components of firm growth, using the SGR as a growth proxy. With REIT legislation introducing legislative limits on financial leverage and dividend retention, we expected that the new structure may have significantly altered the components of sustainable growth and their impact on driving REIT value (as represented by Tobin Q) from the preREIT to the REIT period. With legislation informing REIT dividend distributions and leverage levels, the capital capacity of firms is potentially constrained. Hereby, a firm's ability to grow its real estate investment portfolio may be adversely affected, influencing firm value.

The results of this study display an increase in sustainable growth and profitability since the introduction of the SA REIT structure in 2013, which has enabled REITs to offer shareholders long-term stable and even increasing returns. As a result, REITs appear to have become more attractive to shareholders, making them more competitive and stimulating future shareholder investment, which in turn may increase future profitability and growth. This study also confirms that leverage and profit retention diminished after the introduction of legislation, suggesting that the new legislation may limit capital availability. Additionally, our investigation of the impact of these changing SGR components on firm value reveals that increasing leverage is associated with lower firm value in the REIT period.

Our regression results emphasise the positive impact of retention rates on firm value, particularly in the unregulated pre-REIT period. The significance of financial leverage in determining firm value is evident in the REIT period, with increasing debt levels associated with lower firm value, suggesting that, relative to the pre-REIT period, high levels of debt are less advantageous to REITs because they are penalised by legislation, with an adverse effect on firm value.

The significance of the study for REIT practitioners lies in: (1) providing an understanding of the impact of legislative changes on sustainable growth in the REIT industry, and (2) revealing key drivers of firm value for this particular industry. As a result, practitioners may be better equipped to evaluate and improve sustainable growth and firm value in the SA REIT industry. The present study did not evaluate the growth opportunities available to SA REITs when assessing firm value. Considering the changing macro-environment and regulatory landscape of SA REITs, this is an avenue that can be addressed in future research.

\section{Acknowledgements}

We thank Prof. Martin Kidd (Stellenbosch) for his assistance with this study.

\section{Competing interests}

The authors declare that they have no financial or personal relationships that may have inappropriately influenced them in writing this article.

\section{Authors' contribution}

N.W. was the project leader of the research project and R.C. collected and analysed the data.

\section{References}

Ambrose, B.W., Highfield, M.J. \& Linneman, P.D., 2005, 'Real estate and economics of scale: The case of REITs', Real Estate Economics 33(2), 323-350. https://doi. org/10.1111/j.1540-6229.2005.00121.x 
Ashta, A., 2008, 'Sustainable growth rates: Refining a measure', Strategic Change 17(5-6), 207-214. https://doi.org/10.1002/jsc.827

Barclay, M.J., Smith, C.W. Jr \& Morellec, E., 2006, 'On the debt capacity of growth options', The Journal of Business 79(1), 37-59. https://doi.org/10.1086/497404

Belgrove, J.B. \& Van der Merwe Smit, E., 2016, 'The controllable determinants of liquidity in the context of securitised real estate companies in South Africa', Management Dynamics 25(1), 2-15.

Brounen, D. \& De Koning, S., 2012, '50 years of real estate investment trusts: An international examination of the rise and performance of REITs', Journal of Real Estate Literature 20(2), 197-223.

Capozza, D.R. \& Seguin, P.J., 2000, 'Debt, agency, and management contracts in REITs: The external advisor puzzle', Journal of Real Estate Finance and Economics 20(2), 91-116. https://doi.org/10.1023/A:1007869019657

Case, B., Hardin, W.G. III \& Wu, Z., 2012, 'REIT dividend policies and dividend announcement effects during the 2008-2009 liquidity crises', Real Estate Economics 40(3), 387-421. https://doi.org/10.1111/j.1540-6229.2011.00324.x

Fama, E.F. \& French, K.R., 1999, 'The corporate cost of capital and the return on corporate investment', The Journal of Finance 54(6), 1939-1967. https://doi. org/10.1111/0022-1082.00178

Fama, E.F. \& French, K.R., 2002, 'Testing trade-off and pecking order predictions about dividends and debt', The Review of Financial Studies 15(1), 1-33. https://doi. org/10.1093/rfs/15.1.1

Farooq, M.A. \& Masood, A., 2016, 'Impact of financial leverage on value of firms: Evidence from cement sector of Pakistan', Research Journal of Finance and Accounting 7(9), 73-77.

Feng, Z., Ghosh, C. \& Sirmans, C.F., 2007, 'On the capital structure of real estate investment trusts (REITs)', Journal of Real Estate Finance and Economics 34(1), 81-105. https://doi.org/10.1007/s11146-007-9005-2

Feng, Z., Price, S.M. \& Sirmans, C.F., 2011, 'An overview of equity real estate investment trusts (REITs): 1993-2009', Journal of Real Estate Literature 19(2), 307-343.

Financial Times, n.d., 'JSE FTSE Top 40', viewed 02 February 2017, from https:// markets.ft.com./data/indices/tearsheet/constituents?s=JTOPI:JNB.

Firer, C., Ross, S.A., Westerfield, R.W. \& Jordan, B.D., 2012, Fundamentals of corporate finance, 5th edn., McGraw-Hill Higher Education, London.

Ghosh, C. \& Sun, L., 2014, 'Agency cost, dividend policy and growth: The special case of REITs', Journal of Real Estate Finance and Economics 48(4), 660-708. https:// doi.org/10.1007/s11146-013-9414-3

Giambona, E., Harding, J.P. \& Sirmans, C.F., 2008, 'Explaining the variation in REIT capital structure: The role of asset liquidation value', Real Estate Economics 36(1) 111-137. https://doi.org/10.1111/j.1540-6229.2008.00209.x

Hada, T. \& Avram, T.M., 2014, 'The profit and loss account and the DuPont analysis Study models of performance in companies listed on BSE', WSEAS Transactions on Business and Economics 11, 592-607.

Hardin III, W. \& Hill, M.D., 2008, 'REIT dividend determinants: Excess dividends and capital markets', Real Estate Economics 36(2), 349-369. https://doi.org/10.1111/ j.1540-6229.2008.00216.x

Harrison, D.M., Panasian, C.A. \& Seiler, M.J., 2011, 'Further evidence on the capital structure of REITs', Real Estate Economics 39(1), 133-166. https://doi. org/10.1111/j.1540-6229.2010.00289.x

Higgins, R.C., 1992, Analysis for financial management, 3rd edn., Irwin, Boston, MA.

Holliday, C., 2001, 'Sustainable growth, the DuPont way', Harvard Business Review 79(8), 129-134.

Investopedia, n.d., DuPont identity, viewed 25 February 2019, from https://www. investopedia.com/terms/d/dupontidentity.asp

Investopedia, n.d., Sustainable growth rate - SGR, viewed 25 October 2017, from https://www.investopedia.com/terms/s/sustainablegrowthrate.asp.

JSE, n.d., Real estate investment trusts (REITS), viewed 02 February 2017, from www. jse.co.za/content/JSEPresentationltems/REITs.pdf.
Kantilal, H., 2016, 'An analysis of the real estate investment trust tax regime on the South African property sector', MComm thesis, North-West University, Potchefstroom.

Lang, L., Ofek, E. \& Stultz, R.M., 1996, 'Leverage, investment and firm growth', Journal of Financial Economics 40(1), 3-29. https://doi.org/10.1016/0304-405X(95)00842-3

Lin, F. \& Chang, T., 2011, 'Does debt affect firm value in Taiwan? A panel threshold regression analysis', Applied Economics 43(1), 117-128. https://doi.org/10.1080/ 00036840802360310

Linneman, P.D., 1997, 'Forces changing the real estate industry forever', Wharton Rea Estate Review 1(1), 1-12.

Liow, K.H., 2010, 'Firm value, growth, profitability and capital structure of listed real estate companies: An international perspective', Journal of Property Research 27(2), 119-146. https://doi.org/10.1080/09599916.2010.500459

Ma, G. \& Michayluk, D., 2014, Dividend policy and growth: Evidence from Asian REITs, viewed 02 February 2017, from http://www.asres.net/AsRES Papers/ asres2014_submission_117.pdf.

Naidoo, H, 2014, 'The introduction of REITs to the South African property market: Opportunities for fund managers', Master's thesis, Faculty of Commerce, Law and Management, Wits Business School, University of the Witwatersrand, Johannesburg.

National Treasury, 2012, Explanatory memorandum on the Taxation Laws Amendment Bill, 10 December 2012, National Treasury, Pretoria.

Ott, S.H., Riddiough, T.J. \& Ha-Chin, Y., 2005, 'Finance, investment and investment performance: Evidence from the REIT sector', Real Estate Economics 33(1), 203235. https://doi.org/10.1111/j.1080-8620.2005.00117.x

Pavlov, A., Steiner, E. \& Wachter, S., 2016, 'REIT capital structure choices: Preparation matters', Real Estate Economics 44(1), 1-50. https://doi.org/10.1111/j.1540 6229.2010.00284.x

Pellika, J.R.K., 2009, 'Comparing lodging REITs using DuPont analysis: Evaluating shareholder equity', MSc thesis, North Dakota State University, Fargo, North Dakota.

Property News, 2016, 'Municipal electricity costs raise the cost of living', South African Real Estate Investor, July, p. 6.

Propertywheel, 2017, Rates watch re-appointed by SAPOA to monitor rates policies, viewed 25 October 2017, from https://propertywheel.co.za/2017/02/rateswatch-re-appointed-by-sapoa-to-monitor-rates-policies/.

Rapp, L., 2015, 'Market capitalisation of SA REITs increased around 43\% over past year', Propertywheel, viewed 02 November 2016, from http://propertywheel. co.za/2015/08/market-capitalisation-of-sa-reits-increased-around-43-over-pastyear/.

Rozeff, M.S., 1982, 'Growth, beta, and agency costs as determinants of dividend payout ratios', Journal of Financial Research 5(3), 249-259. https://doi.org/ 10.1111/j.1475-6803.1982.tb00299.

SA Commercial Prop News, 2015, REITs excel among South Africa's top listed companies, viewed 02 November 2016, from http://www.sacommercialpropnews. co.za/property-investment/7730-reits-excel-among-south-africa-top-listedcompanies.html.

SA REIT Association, 2016a, What is SA REIT?, viewed 02 November 2016, from http:// www.sareit.com/101_WhatlsReits.php.

SA REIT Association, 2016b, Real Estate Investment Trusts (REITS) shine among the JSE's most empowered companies, viewed 02 November 2016, from http://www. sareit.com/news-302.php.

Stein, J.C., 2003, 'Agency, information, and corporate investment', in G. Constantinides, M. Harris \& R. Stulz (eds.), Handbook of the economics of finance, pp. 111-153, Elsevier/North-Holland, Boston, MA.

Titman, S. \& Wessels, R., 1988, 'The determinants of capital structure choice', The Journa of Finance 43(1), 1-19. https://doi.org/10.1111/j.1540-6261.1988.tb02585.x

Trading Economics, n.d., South Africa interest rate 1998-2017, viewed 02 February 2017, from http://www.tradingeconomics.com/south-africa/interest-rate.

Wang, K., Erickson, J. \& Gau, G.W., 1993, 'Dividend policies and dividend announcement effects for real estate investment trusts', Journal of the American Real Estate and Urban Economics Association 21(2), 185-201. https://doi.org/10.1111/15406229.00607 


\section{Appendix 1}

TABLE 1-A1: Sample of real estate investment trusts used for analysis.

\begin{tabular}{|c|c|c|}
\hline Number & REIT name & Listed or delisted \\
\hline 1 & Acucap Properties Ltd & Delisted \\
\hline 2 & Arrowhead Properties B & Delisted \\
\hline 3 & Ascension Property Ltd A & Delisted \\
\hline 4 & Capital Property Fund & Delisted \\
\hline 5 & Delta Property Fund Ltd & Listed \\
\hline 6 & Emira Property Fund & Listed \\
\hline 7 & Fortress Income Fund A & Listed \\
\hline 8 & Fountainhead Property Trust & Delisted \\
\hline 9 & Growthpoint Property Ltd & Listed \\
\hline 10 & Hospitality Property Fund A & Listed \\
\hline 11 & Hyprop Investments Ltd & Listed \\
\hline 12 & Intu Properties Plc & Listed \\
\hline 13 & Investec Property Fund Ltd & Listed \\
\hline 14 & Oasis Crescent Property Fund & Listed \\
\hline 15 & Octodec Investment Ltd & Listed \\
\hline 16 & Orion Real Estate Ltd & Listed \\
\hline 17 & Premium Properties Ltd & Delisted \\
\hline 18 & Rebosis Property Fund Ltd & Listed \\
\hline 19 & Redefine Properties Ltd & Listed \\
\hline 20 & Resilient REIT Ltd & Listed \\
\hline 21 & SA Corporate Real Estate Ltd & Listed \\
\hline 22 & Sycom Property Fund & Delisted \\
\hline 23 & Synergy Inc Fund Ltd A & Listed \\
\hline 24 & Texton Property Fund Ltd & Listed \\
\hline 25 & Vukile Property Fund Ltd & Listed \\
\hline
\end{tabular}

REIT, real estate investment trusts. 